\title{
Knock, Knock: The Taxman's at Your Door! Practice Sense, Empathy Games, and Dilemmas in Tax Enforcement
}

\author{
Carlene Beth Wynter ${ }^{1}$ (D) - Lynne Oats ${ }^{2}$ (D)
}

Received: 18 July 2018 / Accepted: 30 September 2019 / Published online: 12 October 2019

(c) The Author(s) 2019

\begin{abstract}
Tax administrators are empowered by the state to secure compliance with tax obligations. Enforcing compliance on the ground is complex, and street-level administrators often engage in the "art of the possible," leading to dilemmas in the field. This paper examines tax administrators' practices with regard to Jamaican property tax defaulters with outstanding tax liabilities in excess of 3 years. Drawing on interviews with tax administrators and other key agents, we find that tax administrators reposition themselves from objective enforcers to empathizing officials engaging in schemes of action, doing what they can do rather than what they should do. This is a practical-sense approach to securing compliance. We identify two forms of empathy, assimilated and cynical, and conclude that administrators' empathetic identification with defaulters does not necessarily arise solely from concern for social cohesion, or inter-subjective compassion, but also sometimes from self-interest.
\end{abstract}

Keywords Dilemmas $\cdot$ Empathy games $\cdot$ Practical sense $\cdot$ Tax administration practices

\section{Introduction}

"We are asked to collect $15 \%$ of the arrears and $62 \%$ of the current years' liabilities. What do you do," asked a senior tax administrator, "when defaulters sometimes don't turn up to court, when a defaulter is ill but owes more than a $\$ 1 \mathrm{~m}$ in taxes or when a defaulter hides from the tax authority during the regular work hours but can be found on a Sunday?"

Tax administrators are empowered by the state to carry out their main task of securing tax compliance (Bird and Zolt 2014; Björklund Larsen 2013, 2015, 2017; Boll 2011, 2014; Wynter and Oats 2018), and are expected to raise tax revenues to enable the state to carry out its obligations (Bräutigam 2008; Martin et al. 2009). Defaulting taxpayers must be found and made to pay. "Tax administrators ...

Carlene Beth Wynter

c.wynter@aston.ac.uk

Lynne Oats

1.m.oats@exeter.ac.uk

1 Aston Business School, Aston University, Aston Triangle, Birmingham B4 7ET, UK

2 Exeter Business School, University of Exeter, Rennes Drive, Exeter, Devon EX4 4PU, UK are specifically entrusted with powers of tax enforcement through tax regulations to ensure that citizens are accountable to the state through compliance and payment of ... their tax" (Wynter and Oats 2018). Nevertheless, enforcement on the ground is complex, and street-level tax administrators engage in the "art of the possible" (Tanzi and Zee 2001, p. 2 ), that is, using unconventional methods when necessary.

In developing countries, tax administrations' enforcement activities are often undermined by weak institutions, challenging socioeconomic environments (Alm and MartinezVazquez 2007; Mansfield 1988; McKerchar and Evans 2009; Tennant and Tennant 2007; Vehorn 2011), overburdened court systems (Cornia and Walters 2010), and resource constraints. In addition, tax legislation may be insufficient (Gill 2000), tax rolls may be outdated (McCluskey and Franzsen 2005), prohibitive cultural practices may sometimes be embedded in the tax administration's practices (Nerré 2008; Wynter and Oats 2018), and tax morale, that is, willingness to pay tax, is often low (Bahl and Wallace 2007). Despite these challenges, the state still expects tax administrators to meet their revenue collection targets (Bird and Zolt 2014; Browde 2017). Regulation scholars note that to meet their objectives, street-level bureaucrats adopt various enforcement styles, ranging on a continuum from legalistic, where they stick strictly to the rules, to accommodative, where they are sympathetic to the regulatee's context (see, for example, 
Hutter 1989; May and Winter 2000; May and Wood 2003; McAllister 2010; Nordin et al. 2017). Tax administrators with an enforcement role are a particular category of regulator whose work is complicated by the need not only to secure compliance with regulatory requirements, but also to extract funds from the regulatee. They similarly have differing enforcement styles.

Recent years have seen the promotion of softer approaches to safeguarding compliance that involve developing relationships with taxpayers. For example, Alm and Torgler (2011, p. 635) call for a "kinder and gentler tax administration to enforce compliance," and Alasfour (2017) advocates the development of a trust-based culture to achieve this (see also Murphy 2005, 2008). Tax authorities are known to use friendly persuasion (Chung and Trivedi 2003) or to treat taxpayers as customers, requiring personalized, relational interactions (see Tuck 2010). Previous studies (see, for example, Bernstein and Lü 2008; Cullis and Lewis 1997) have shown that where softer approaches are used, compliance tends to increase. The International Monetary Fund (IMF) emphasizes the need for tax administrators to engage in "amicable" relational practices in their bids to enforce compliance on tax defaulters (Silvani and Baer 1997).

Despite this support, little research has been carried out on how tax administrators actually engage in amicable practices to enforce tax payment. In this paper, we explore the use of amicable practices in Jamaican property tax collection, focusing on the use of empathy in dealing with defaulters. We draw on interviews with tax administrators and other key agents in the property tax field to provide insights into tax administrators' relational approaches, interactions, and enforcement practices. In theory, property tax is difficult to evade, but in practice it presents enforcement challenges because of its complex administration (Bahl 2009; Bahl and Bird 2008; De Cesare 2004; Martinez-Vazquez and Sepulveda 2011, p. 2; Wynter 2014). We introduce a new way of thinking about regulatory enforcement and add to the literature on regulatory practices in the tax field (Braithwaite 2003, 2006, 2009; Gracia and Oats 2012), and specifically tax administrators' practices (Björklund Larsen 2013, 2015, 2017; Boll 2011, 2014; Pentland and Carlile 1996; Tuck 2010; Wynter and Oats 2018).

We find that a country's tax administration practices develop not only through formal legislation, but also from tax administrators' practices (Bird 2015). As Boll (2011) notes, street-level tax administrators can be viewed as policy makers in how they do their work, so it is important to understand how and why they work in particular ways. Inspired by Bourdieu's framework of practical sense (Bourdieu 1977, 1998, 1990; Bourdieu and Wacquant 1992), we suggest that empathy forms part of the individual and organizational enforcement practices of the Tax Administration of Jamaica (TAJ). We find evidence of tax administrators repositioning themselves from objective enforcers to empathizing officials, seeking to identify with defaulters' circumstances to secure compliance by using two empathy games: assimilated and cynical. A practical-sense framework enables a better understanding of interactions in practice, and of tax administrators' schemes of actions-doing what they can do, rather than what they should do to enforce compliance.

The paper proceeds as follows: The next section outlines the theoretical framing of the study, including a brief discussion of the notions of practical sense and empathy. The study is then contextualized, and the research methods explained, outlining how the data were collected and analyzed. Following this, the results are presented and discussed, and conclusions drawn.

\section{Practical Sense and Empathy Games in Tax Practices}

In the social world, agents' dispositions interact with field conditions, giving agents a "feel for the game" (Bourdieu 1990, pp. 65-66). This feel for the game is more than just understanding the rules of the game. It concerns awareness and appreciation of the game, its complexities, and its "ins" and "outs," and is a way of making sense of agents' actions: "feel for the game is what gives the game a subjective sense- - a raison d'etre, but also a direction, an orientation impending outcome for those who take part and therefore acknowledge what is at stake" (Bourdieu 1990, p. 66). This is a practical-sense approach. Practical sense, then, is an acquired system of preferences, and principles of vision (what we see) and division (how we classify things), as well as a system of durable cognitive structures and schemes of action that orient perceptions of and appropriate responses to situations (Bourdieu 1998, p. 25). In this paper, we argue that these schemes of action and responses are the "coulds"- the possibilities or games in which tax administrators engage to enact enforcement. Such games may not be rule-based because, as Bourdieu (1990, p. 103) argues, "practical sense does not burden itself with rules or principles, practical sense goes beyond rules of the field, and beyond past practices, to invent new practices." In some fields, some agents (such as economists in the field of economics) are credited with an ability to assess objective choices rationally, and to self-regulate mechanisms in the field, with absolute power to determine preferences (Bourdieu 1990, p. 81) or preferred courses of action. However, within social practices such as taxation, accounting, and politics, agents are more inclined to do whatever is necessary, or resort to games to achieve their desired ends (Bourdieu 1990). Such game playing is given various labels, such as tact, skill, dexterity or delicacy, but according to Bourdieu (1990), all comprise practical sense. 
In this study, we observed tax administrators engaging in a form of practical sense-empathy-to enforce compliance. Despite a plethora of studies of empathy, there is no coherent definition. Head (2016) describes the concept as messy, personal, complex, and difficult to define (see Head 2016, pp. 95-96), and a core capacity of humans. Others describe it as a basic capacity or a skill. Whether or not empathy is a moral virtue is subject to debate (see Battaly 2011; Bubandt and Willerslev 2015). Lohmann (2011, pp. 113-114) argues that it can be fostered as a skill, and notes that it can be neglected or developed in different ways and in different circumstances, and is therefore situational (Hollan and Troop 2011, p. 206). We take the view that empathy can be developed as a skill (Lobb 2017), and is not necessarily tied to the moral makeup of an individual (Prinz 2011), but is context-dependent. We suggest that different types of empathy may be manifested, depending on the situation faced by agents, creating space for agents to switch between different types of empathy.

Empathy entails a perspective on another person's thoughts and feelings, as if agents were experiencing and understanding the world from the other person's vantage point (Hollan and Troop 2011, p. 3, citing Halpern 2001), walking "in the shoes of the other" (Head 2016, p. 102) while maintaining their own identity (Rufkin 2009). It also gives agents the capacity to both establish and maintain social bonds and to understand and negotiate social relationships (Gruen 2014, p. 93; Komorosky and O'Neal 2015). The consequences of empathy are concern for others (Coke et al. 1978; Hoffman 2001; Hollan 2008), "compassionate behaviour towards others, moral agency and ethical behaviour based on mercy and justice" (Hollan 2012, citing Harris 2007 , p. 169). However, empathy may not always be compassionate, moral or ethical, as "empathic identifications with others do not [necessarily] have as their goal mutual understanding, altruism, consolation, inter-subjective compassions, care or social cohesion" (Bubandt and Willerslev 2015, p. 6; Halpern 2001; Shapiro 2014, pp. 279-280).

We identify two particular forms of empathy, assimilated and cynical, each tied to the type of defaulter encountered by the administrator. Assimilated empathy means understanding the other's mind-set, driving emotions or outlook, but without necessarily sharing or approving of the other's thoughts, feelings, and perceptions; it entails assimilating diverse information about the other (Coplan 2011; Galinsky et al. 2008; Halpern 2001, 2014; Vann 2017; Waldman 2014) in a genuine attempt to walk in their shoes. Cynical empathy, on the other hand, is the strategic use of an impression of empathy in order to achieve a specific objective; it lacks emotional engagement and meaningful understanding of the other. Here, there is a sort of detachment, where concern for the other is switched off, and empathy may become merely an intellectual exercise, remaining squarely in the position of "getting, acquiring, a tool to obtain an objective even though a good one is met" (Shapiro 2014, p. 279). Not all tax administrators will display either assimilated or cynical empathy, but where they do, it may be in one or other form, or a mixture of the two.

We find that where defaulters are more responsive, assimilated empathy is used: when defaulters appear to be more amenable to enforcement, tax administrators are more likely to show genuine concern for them (Coplan 2011; Galinsky et al. 2008; Halpern 2001, 2014; Vann 2017; Waldman 2014). Where defaulters are more resistant to enforcement, cynical empathy is more likely to come into play.

We make the case that identifying with defaulters lies at the heart of tax administrators' empathic imagination. Streetlevel tax administrators are able to resort to empathy games based on their perceptions of defaulters' circumstances and responsiveness to enforcement efforts. Moving between their own ideas and the perspectives of defaulters, as well as identifying with defaulters' points of view, provides tax administrators with opportunities to obtain in depth understandings of defaulters' mind-sets and motivations, creating space for resourceful and creative practices.

\section{Research Method}

This paper derives from a wider study of property tax administration practices, for which interview fieldwork was undertaken in Jamaica in 2012, 2013, and 2016 by the first author. Other sources of data included articles, newspapers and government documents such as TAJ's Citizen's Charter (2016), and the Auditor General's Report (2016) which reviewed TAJ's performance for approximately a 6-year period up to 2016.

Thirty-five face-to-face, semi-structured interviews were conducted over a 19-week period. Subsequent clarification through telephone calls, social media, follow-up interviews, and emails was sought from selected interviewees. Participants were purposefully selected (Creswell 2013; Marshall 1996; Merriam 2002; Patton 1990; Silverman 2013; Tracy 2010; Miles and Huberman 1994), and represented a wide range of agents, including taxpayers, senior tax administrators (the Commissioner General, the Property Tax Co-ordinator, two Property Tax Regional Managers and a former Director of Internal Revenue), tax compliance officers, cabinet ministers, a former prime minister, senior government bureaucrats, and politicians.

We solicited cabinet ministers' and legislators' perspectives, based on their intimate involvement in the creation of both property tax policy and legislation. Emphasis was placed on tax administrators' perspectives, owing to their connections and interactions with defaulters and engagement with enforcement. Obtaining data on some taxpayers' 
compliance status was a challenge, since non-payment is illegal. All participants in this study are anonymized. All interviews except one were audio-recorded and subsequently transcribed verbatim. The texts were coded and thematically analyzed (Braun and Clarke 2006), using QSR NVivo to assist in analyzing and managing the data and to establish an audit trail (Bringer et al. 2006, p. 33).

In the initial stage of analysis, we established that interviewees discussed high levels of evasion, visits to communities, evaders' responses when they are caught, and games played to enforce compliance. Additional analysis then gave us deeper insights into empathy games, revealing that administrators' perceptions of defaulters influence the types of empathy games they play (Bubandt and Willserslev 2015; Coplan 2011; Halpern 2014; Vann 2017; Shapiro 2014; Wispé 1986). This led us to the question of how do administrators engage in empathy games in their practice of enforcing payment of property tax in Jamaica?

\section{Property Tax Administration}

The Jamaican property tax is a local tax, payable annually by owners, occupiers, mortgagors, or anyone in actual possession of the property when payment becomes due. Property tax revenues are important for the survival of Jamaican local authorities' infrastructural development and provision of local community services, such as garbage collection, street lighting, and community beautification (see Government of Jamaica 1996-National Land Policy; Local Authorities of Jamaica 2016). High evasion rates threaten, and occasionally impair, the effectiveness of local authorities' operations. Property tax administration is hampered by an overstretched court system, inadequacy of the legislation, lack of political support for some enforcement strategies and outdated tax rolls (Cornia and Walters 2010), informal land tenure practices (Beale and Wyatt 2017; Clarke 1999; Wynter and Oats 2018), adverse socioeconomic conditions, a large informal economy, and resource constraints (Cornia and Walters 2010; Wedderburn et al. 2012), as well as taxpayers' unwillingness to pay tax (Bahl and Wallace 2007), i.e., low tax morale. High levels of tax evasion result in significant arrears, reduction of which is a target for the tax administration and a performance criterion for regional managers.

In exploring tax administrators' empathy games, the empirical focus of this study was on the reminder system, a property tax enforcement strategy implemented in Jamaica in 2006 to tackle large-scale evasion. We examined how tax administrators use their experiential and procedural knowledge to manage defaulters' behavior, through delivery of assessment notices, and visits to defaulters' properties. We noted how defaulters' liabilities are enforced, and observed administrators' interactions with defaulters and identification with defaulters' perspectives and feelings. As a result, we are able to provide deeper insights into tax administrators' practical-sense approach, as reflected in their empathy games.

The fundamental concept of the reminder system is to locate, visit and hand-deliver notices to defaulters, establish relationships with them, and bring them under the gaze of the TAJ, with the ultimate goal that they pay their outstanding liabilities and continue to do so in future. Receipt of an assessment notice is a precondition for enforcement. Locating the defaulter initiates a personal interaction, providing tax administrators with an opportunity to identify with the defaulter's circumstances (Halpern 2014), and both step into and step back from the defaulter's perspective. Depending on the empathy game played, some defaulters may become more visible and more compliant with TAJ, while others remain outside its gaze and non-compliant.

In their practices and interactions with taxpayers, tax administrators are guided by the Citizen's Charter introduced in 2011. Its introduction came within the broader ambit of the public-sector modernization program that commenced in 1994 (see Government of Jamaica 2012—Report, Offices of the Services Commissions), but more specifically in response to the IMF's tax reform conditions in its 2011 standby agreement. Under the Charter, services are built around IMPACT: integrity, mutual respect, professionalism, accountability, customer-centric strategies, and team work. Its importance is underscored in TAJ's National Compliance Plan (2017/2018), articulating its focused commitment to its clientele, including expected service standards, taxpayers' rights and obligations, and appropriate channels for expressing grievances or complaints. Notably absent from the Charter is taxpayers' right to privacy. However, this issue is addressed by the Jamaican Constitution, with the courts stipulating when taxpayers may be visited for enforcement purposes. Despite the absence of this provision, Financial Secretary, Dr Wesley Hughes, noted in the Charter that it is the "public's score card for rating TAJ's performance against the targets set" (see TAJ 2012), although there seems to be no information on how this rating can be achieved. Other details of the legislative requirements of the property tax are given in the appendix.

\section{Performance Targets}

Evidence from the field reveals that tax administrators' and other revenue agents' job tenure is predicated on them meeting performance-based revenue targets -15 percent of arrears and 62 percent of current liabilities (STA31 \& STA32) — which are converted into hard annual and monthly targets for each collecting region and local authority. When targets are not met, reasons must be given. According to 
a senior tax administrator (STA31), failure to meet these targets carries severe career consequences such as "reassignment," presumably to other positions in TAJ. In extreme cases, it may lead to termination of employment, as stated by a senior government bureaucrat (GB01). Participant STA31 continued, "when I can't make my target, it is stressful, you feel like you would pull out your hair." But another administrator, apparently unperturbed by the targets, stated, "we just do what we can." This chimes with the observation of a mayor, who said:

Well, the government tell you what they want, but I don't pay any mind to it. We do what we can do. My approach is that you just can't say a percentage. We do the best we can with the resources we have (PP11).

Meeting their targets is an organizing principle for administrators' collection and enforcement practices. Although enforcement should ideally target all defaulters, TAJ's collection practices tend to "focus on numbers, so their enforcement activity is at the big players who pay a lot of money and consequently, you find that a lot of persons who have been regularly non-compliant continue to be" (Senior bureaucrat GB03). However, some interviewees believed otherwise, stating, "in Jamaica, the big men don't pay tax" (Senior bureaucrat GB06). Consequently "there are [lots of] rich people who are not paying," because "TAJ seemed to target small taxpayers because they know it is collectable" (Taxpayers TP24 \& TP21). To meet their targets, TAJ confirmed that they concentrate on more feasible liabilities: "those with J\$2000 (£13.33) or less is just not on" (STA30). Evidence suggests, for example, that the general practice is not to enforce against some large landowners while collecting from others, depending on the story told by owners. Some owners with inaccessible land are left alone because "they would not want to pay" (Senior administrator STA33). In other cases, land is deemed accessible but "transfer of their land may not have been effected after sale for a certain time," so even if pursued, they would be taking "a node of the decision tree that is going to lead to zero" (Senior administrator STA29). Furthermore, it is known within the tax field that, based on their knowledge of the law and their financial resources, landowners may resist enforcement attempts (GB01). Therefore, tax administrators are well aware that enforcing compliance may embroil TAJ in lengthy legal battles, especially with "trouble delinquents" (GB01), which may be counterproductive, ultimately yielding no additional revenues. Despite the challenges associated with the court system, one senior administrator (STA32) noted that as soon as summons are served, "defaulters find the money to pay." Notwithstanding their effectiveness, summonses are used as a last resort owing to their cost and administrative difficulties. Given the field conditions (see Beale and Wyatt 2017; Cornia and Walters 2010; Wynter and Oats 2018), TAJ adopts a practical-sense approach (Bourdieu 1990, 1998) to enforce those liabilities they consider feasible. They "decide which battles to fight, which one is material, what has to be delivered and which ones can be won in a short time" (GB01).

\section{Enforcement Processes}

Collecting outstanding liabilities relies on knowledge of and access to defaulters (Dillinger 1992). One senior administrator (STA31) advocated a perpetual access system to defaulters: "We want a system where we can go at night, any time of the night, any time of the day, on a Saturday, Sunday, 24/7." 1 The Supreme Court of Jamaica grants defaulters a limited right to privacy, preventing enforcement by summonses on Sundays and public holidays. However, TAJ engages municipal officers to serve reminder notices on Sundays, especially near "to crunch time, end of financial year, to get everything we can" (STA31).

Since some defaulters are known to hide from TAJ, a major part of an administrator's job involves searching for them (Cabinet minister PP14). According to a compliance officer, "I work on the road, I look for delinquent taxpayers, the ones that are hiding, the ones that are not paying" (TCO01). On the other hand, some defaulters who are in full view of TAJ are not enforced against. In this regard, one administrator said:

I will be listening to the radio and hear some people talking about what government need to do. I am sitting there, and I know that these people do not pay [property] tax. But what can I do? I have to keep quiet (STA31).

For those whom TAJ perceives it can enforce against, administrators decide where and for whom to search by reviewing the arrears register to establish the extent and conditions of the debt, supported by information on exact locations from previously caught defaulters. Compliance officers "go door to door, community by community" (PP12, STA31), "staying in a community until some money is collected" (STA32). It was revealed that gated communities have particularly high delinquency rates and access challenges. While some allow access to administrators on presentation of their identification, at others, security officers refuse entry for fear of losing their jobs.

\footnotetext{
${ }_{1}$ Defaulters do not know when they will be served with summonses. Service times are Mondays to Saturdays, 6.00 am to $6.00 \mathrm{pm}$. According to a senior tax administrator (STA31), some defaulters avoid these times to stay outside the net. Although a Sunday service might improve enforcement, the legislation does not allow for this.
} 
Once defaulters are located, "it was very refreshing to have a one on one with them, as they are the same ones who will assist in locating other taxpayers" (STA31). However, one tax compliance officer (TCO01) painted another picture, reporting that some are "rude, annoying and tedious." Regardless of their reactions, defaulters are served with their reminder notices, giving details of their current year's liability, their outstanding liabilities listed year by year, and two options: either to settle their outstanding liability within 15 days, or to contact the tax authority using the telephone number provided.

Street-level tax administrators working in the field play an important role, listening to and interfacing with defaulters strategically to obtain information about their circumstances, their current addresses, and their connection with the property. This information is then used to update the tax roll (GB01). This brings these defaulters under TAJ's gaze, providing it with more knowledge of and access to them, and thereby enabling it to exercise more influence over them, which is a key factor in collecting (Powers 2008). In addition, physically locating them and obtaining this information significantly reduces TAJ's search costs, ensuring that people entered on the roll as owners/occupiers are the true owners/occupiers of their land (Beale and Wyatt 2017, p.20).

Choosing option two, to contact TAJ, heralds the commencement of an intense personal relationship with TAJ, creating opportunities for tax administrators to listen, become curious and build narratives of defaulters, all of which helps them to identify and imagine defaulters' circumstances. When defaulters make contact with TAJ on the telephone number given, TAJ logs their names, contact details, and liabilities in its register of collections:

We have a book over there [shows first author the record book]. They call, we put their names, the date, the amount that is outstanding, and when they are coming into pay. They say they can pay in two weeks. So we give them dates, we follow up. Every morning we have a page, and all the persons who are scheduled to pay in the next few days are called (STA32).

Some defaulters face high compliance costs owing to transportation challenges. A cabinet minister confirmed that, for some defaulters, "it costs more in transportation costs to go to pay the tax, than the tax itself" (PP17). Although an online system might solve this problem, these defaulters are unlikely to have access to such a system, despite internet availability. ${ }^{2}$ Realizing that evasion is not necessarily a

\footnotetext{
${ }^{2}$ Jamaica has a huge informal economy (Gill 2000), believed to amount to 40 percent of its GDP (see Wedderburn et al. 2012). This limits defaulters' access to credit cards, a condition for using an online system (see also Graham 2016).
}

deliberate choice (see, for example, Hasseldine and Li 1999), and in keeping with its scheme to offer amicable strategies, TAJ's response has been to provide outstations (temporary collection stations) to make it more convenient and cheaper for defaulters to pay. In the words of one senior administrator (STA32), "we know it takes two buses to come here, so we try to go to them," showing consideration for their circumstances. However, providing outstations raises dilemmas such as threats of violence against staff, and theft of collections, a perennial issue in Jamaican society (Harriott 2003 , p. 285). Outstations are therefore carefully planned with due cognizance of both convenience and safety issues. With regard to safety, TAJ often places outstations at police stations, as well as engaging security personnel to accompany staff. One tax administrator described this process:

We go out in the rural area and do the collections, and that is when we have security. The police just give us a little area and people come in and pay; at least we know that we are secured. But we have to make sure we have security to take us back with the money (STA31).

In terms of convenience, the practice is to place outstations in rural areas, open at weekends and outside normal working hours to make it easier for defaulters who find it challenging to use the regular stations or the online portal. This is a practical-sense approach to enforcement.

\section{Empathy Games}

Given the system of property tax administration and the field conditions outlined above, how can tax administrators do their job effectively? Among other practical-sense strategies, we found evidence of two forms of empathy games: assimilated and cynical. Each type relates to the tax administrator's own empathetic imagination and perception of the type of defaulter encountered. Where a defaulter is perceived to be more responsive, assimilated empathy is often applied. Cynical empathy, on the other hand, tends to be reserved for those viewed to be uncooperative and less receptive to TAJ's overtures. We now discuss each in turn.

\section{Assimilated Empathy}

Evidence from our study suggests that some tax administrators' identification with and imagination of defaulters' circumstances, through multifaceted empathetic processes (Coplan 2011; Halpern 2014; Vann 2017), results in them showing genuine concern for defaulters. These processes include listening, personal interactions, following narratives of defaulters' experiences, becoming curious about defaulters' circumstances, and offering appropriate support to enforce compliance. 
Administrators' game plan of visiting, recording, and calling is in keeping with TAJ's vision of professionalism and customer centricity (Citizen's Charter 2016). During these calls and visits, the evidence suggests that defaulters provide information about their varied personal situations, to which administrators listen. One interviewee observed:

\section{Sometimes we act as social workers, just listening to their problems; sometimes what they are telling us, we don't even need to know. Sometimes they tell us stuff and we just sit down and listen, and you empathise and you do whatever it is to make them comfortable or feel free to speak with you, and see that you understand what they are going through, you are not there to bring them down (STA32).}

Empathetic tax administrators use listening and interpersonal interactions to understand, interpret, and imagine defaulters' situations (Komorosky and O'Neal 2015). In doing so, they gain a first-person perspective on defaulters' thoughts and feelings (Head 2016, p. 102; Hollan and Troop 2011, citing Halpern 2001), which elicits concern, compassion, and sensitivity.

Further evidence of tax administrators' assimilated empathy is seen in how they absorb and assess knowledge gained of defaulters' circumstances; for example, "their arrears were too large," "they could not afford property tax," "they didn't know that they could pay their tax in installments," "they forgot to pay," or "could not pay because they were sick" (STA31, STA32, TCO01, TP36). Seeing the world through their eyes (Head 2016; Hollan and Troop 2011, p. 3, citing Halpern 2001) and looking behind these statements enables empathetic administrators to make more accurate assessments (Halpern 2014). Identifying with their situations, an administrator said, "I know people are fighting hard times, so we are flexible and are willing to work with [them]" (STA31). Despite the legislative requirement to settle outstanding liabilities within 15 days, "we accommodate them, whatever they have," (STA32), "no matter how small it is, it is better than nothing" (TCO01), "even if it's J $\$ 100$, we take it" (GB01). Some defaulters are micro-managed (STA32) and coached into planning and budgeting, encouraged to save small amounts on a regular basis so they can pay their tax. Administrators drew parallels between the property tax and defaulters' household bills, as it had been found that some defaulters "planned for everything else, even parties, but they don't plan how they will pay their property taxes" (PP11). Such actions reflect tax administrators' sensitivity to defaulters' difficult circumstances (May and Winter 2000), giving them some sort of "compassionate space" (PP14), but at the same time ensuring that some revenues are collected. One defaulter welcomed these practices, noting that it is easier to pay: "they don't pressure you, I try not to allow my taxes to mount up" (TP26). On the other hand, some defaulters scoffed at TAJ's concern, and instead retorted, "they have no teeth, they are weak" (TCO04).

Payment plans, coaching, and budgeting may be seen as attempts to improve defaulters' accountability and maintain social bonds (Gruen 2014), making them law-abiding and thus socially adjusted citizens (Komorosky and O'Neal 2015), which ultimately shapes their morality (Björklund Larsen 2017). Although such practices may be seen as expressions and outcomes of empathy (Björklund Larsen 2017; Hoffman 2001), they raise the question of whether TAJ is fulfilling its ethical mandate to bring justice to the tax field. Defaulters may feel that they are treated fairly, listened to and have a voice, all of which contribute to improving trust, loyalty, and commitment to the tax authority, ultimately increasing compliance (Kornhauser 2006, p. 615; OECD 2010). However, since the law has been broken, the full weight of the law should be applied; yet defaulters are allowed to negotiate payment terms, which means they continue to use services paid for by other taxpayers, thus raising issues of retributive and distributive justice (Elkins 2009). Given the field conditions, such as the overburdened court system, payment plans are probably the only effective strategy for collecting and possibly fostering future compliance (Levi 1988; Murphy 2005, 2008; Nordin et al. 2017). As empathetic as such actions may be, they do not necessarily equate to tax justice because they potentially affect other taxpayers and may lead to evasion by otherwise compliant taxpayers. This is a dysfunctional response in the field. ${ }^{3}$

\section{Cynical Empathy}

Empathy does not always take on the hue of moral agency, with ethical behavior based on mercy and justice (see Hollan 2012); it may have a dark side (see Bubandt and Willserslev 2015; Shapiro 2014; Wispé 1986). Some agents use their understanding of the "other" to project themselves using subtle coercive tactics, demonstrating a sort of detached concern. This is evident in how TAJ deals with defaulters perceived to be less responsive, those it argues "just don't want to pay," for which "they accepted no excuses" (STA31). Such defaulters include those who miss payment deadlines or fail to respond to TAJ's reminders. Those who miss payment deadlines are aggressively pursued and hounded with incessant phone calls.

\footnotetext{
3 Tax administrators target those who are more likely to pay, because this is more cost-effective and efficient (Silvani and Baer 1997) and allows targets to be met more easily. However, this may become dysfunctional. One taxpayer said, "I am annoyed with how they went about dealing with the outstanding amount owing for property tax, and persons who normally pay become delinquent as well."
} 
Sometimes they are tired of us calling. We put on the pressure and then you find out that they will come in. And they would say, "you know I don't get the money yet" and our response would be "but you gave us a date, and the last time you told us you didn't come." We just continue calling until we get most of them [to pay] (STA32).

Where the legislation is deemed inadequate, "the strategy is a mix of persuasion and veiled threats" (STA29). ${ }^{4}$ However, "if defaulters are aware that we don't have the power, we not getting 'zilch' [nothing] from them" (STA30). For defaulters who consistently ignore reminders, "we try to bluff them" (Mayor PP07) by placing "for sale" signs on their properties. On seeing these signs, the defaulters will contact the government, even though some take a long time to do so. Defaulters who owe tax for more than 6 years are made to think that there is a likelihood that they may be asked to pay the outstanding tax beyond the statute bar, along with fines and penalties:

If the government should go back in time and to collect and say this is what you owe, and then you have to pay penalty and interest on the outstanding amount, then this is not good for you. Make your arrangement and pay it off (Compliance officer TCO03).

Not all defaulters buy into this, as some are "unruly had to be summons [sic]" (TCO03). Those with very large balances who make no attempt to pay despite TAJ's contact are prosecuted without regard for their personal welfare. For example:

We have a defaulter who is not paying. He is now ill. He bought the land for agricultural purpose and he got ill. His wife is also sick. He owes property tax for over a J\$ $\mathrm{m}$. It is a lot of money, so we took him to court (STA32).

While some defaulters respond immediately for fear of additional debt, embarrassment, and losing their property (TPC14, TCP15), others take a long time to respond (PP14). When they respond to TAJ, it creates space for tax administrators to display empathetic concern, as "perceiving another person to be in distress prompts helping behavior" (Marsh 2014, p. 197, citing Clark and Word 1974).

The foregoing actions seem less benevolent than patiently "cajoling defaulters into compliance" (Hutter 1989, p. 156). The literature suggests that sometimes, in everyday life, empathy needs a filter for agents to select what they react to, switching off concern for others to secure their objective

\footnotetext{
${ }^{4}$ One interviewee (STA29) conceded that the approach of using veiled threats is not a good enforcement strategy as it involves "making up the law as you go along" (STA29), which he argued sets a bad precedent for future tax administrators.
}

(Bubandt and Willerslev 2015; Hutter 1989; Wispé 1986). Tactics such as incessant calling, veiled threats, bluffing, and taking defaulters to court when both partners are sick might be construed as concern switched off, designed to create distress and fear (Bubandt and Willerslev 2015; Wispé 1986) with a view to securing instant compliance (Hutter 1989).

Tax administrators' actions may not always reflect a deeply held commitment to enforcing compliance, but rather a response to being evaluated with reference to revenue targets. Empathy is applied cynically. Although a moral good is achieved, such actions induce distress in some defaulters, reflecting a disconnect with TAJ's stated organizational ethics (see, for example, Bobek et al. 2010). Since meeting targets determines their career future, tax administrators' enforcement actions are self-interest-oriented, and therefore strategic (Swartz 1997). Administrators play a cynical empathy game (Bourdieu 1990), enforcing compliance not as "conscious conformists to the regulations but as strategists ... moving through a maze of constraints and opportunities ... through past experience and over time" (Swartz 1997, p. 99).

\section{Discussion and Conclusion}

This paper provides deeper insights into practices adopted by tax administrators to tackle large-scale tax evasion by defaulting individual property taxpayers. Specifically, it has explored how tax administrators adopt practical-sense approaches to enact amicable relational enforcement (Alasfour 2017; Alm and Torgler 2011; Chung and Trivedi 2003; Tuck 2010), and how enforcement practices are shaped by tax administrators' and defaulters' dispositions, cognitions, and sentiments (Bourdieu 1990; Bubandt and Willerslev 2015; Swartz 1997). Specifically, we have examined tax administrators' empathy games, deepening our understanding of why and how tax administrators act as they do to arrive at decisions. We note that tax administrators are able to switch between two types of empathy-assimilated and cynical-in enforcing compliance. Each type is not necessarily tied solely to their moral makeup, but also to their perceptions of defaulters, implying that empathy is circumstantial (Hollan 2011, p. 206). Where empathetic administrators perceive defaulters to be more responsive, assimilated empathy is applied, showing some concern for defaulters. On the other hand, where defaulters are perceived to be less responsive or unresponsive, administrators take a more tactical approach to enforcement, displaying a sort of detached or switched off concern that might be construed as a harsh and deceptive example of cynical empathy. Each type of empathy reflects the level or type of justice applied to defaulters.

Our research conceives taxation as a social practice (Boden et al. 2010) and, in conceptual terms, as an 
institution undergirded by agents' “dispositions, cognitions and sentiments" (Bird 2015). The study reveals that incentives facilitate vicarious tax practices where administrators engage in the "art of the possible" (Tanzi and Zee 2001, p. 2), creating new practices in the field (Bourdieu 1990), and giving them space to fulfill their self-interests. Unlike previous work on softer approaches to tax practices, this study provides deeper insights into tax administrators' everyday approaches to enforcement, shaped by their practical sense.

Inspired by Bourdieu's concept of practical sense, we have explored how empathy becomes a part of the enforcement game, and how tax administrators alter their positions from being objective law enforcers to becoming strategic empathizers in the enforcement game, based on their perceptions of defaulters. We have provided deeper insights into tax administrators' actions, showing how identification with defaulters creates opportunities for innovative and new practices in the tax field. Such practices can be perceived as a means to an end, highlighting why practices in some situations do not follow normal tax logic (see Bourdieu and Wacquant 1992, p. 120). Thinking in terms of practical sense improves our understanding of how administrators' awareness and appreciation of the field enables them to interpret the field conditions, and in so doing allows for opportunistic responses, making anticipatory adjustments to the field's demands (Bourdieu 1990). Such practical-sense responses and adjustments may not always be rational or objective, but immediate, pre-reflective, cognitive, and embodied, occurring under conditions that exclude distance, perspective, detachment, and reflexivity (Bourdieu 1990, p. 82). Street-level tax administrators' responses and adjustments are attempts to maintain social bonds (Gruen 2014) by securing defaulters' commitment to and involvement with the property tax to make them accountable (Wynter and Oats 2018). This encourages them to become law-abiding and thus socially adjusted citizens, and is a key element of empathy (Komorosky and O'Neal 2015).

In identifying two types of empathy-assimilated and cynical—we shed light on how tax administrators seek to manage defaulters' otherwise hidden behaviors and decisions (Keen 2008). The study also demonstrates how tax administrators are able to step into and step back from defaulters' thoughts, feelings, and circumstances, and maintain their identities with a determined insistence on defaulters' alterity/otherness (Bubandt and Willerslev 2015, p. 7). Empathy requires both intimate engagement and a measure of detachment (Rifkin 2009, p. 173), and it is this detachment that must be maintained to ensure a difference from the other. If tax administrators' feelings spill completely into those of the defaulters, they will lose a sense of who they are as enforcers, compromising their ability to enforce compliance. Thus, even though they might understand the defaulters' plight as if it were their own, they might be engulfed by it. If this were to happen, it would drown out their ability to be unique and separate from defaulters: they are agents of the state and must be seen as such. This is admittedly a rather fragile balance for them to strike, given that empathy requires a porous boundary between the empathizer and the other that somehow allows the two beings to mingle in a shared mental space (Rifkin 2009). Thus, they must maintain a distinction from the defaulters in order to assess the degree to which defaulters' qualities or responsiveness match with their image or perspectives.

This is a sort of paradox, the play of identification and "othering," which lies at the heart at empathetic faculty and detached concern for "others." For those who are more responsive or co-operative, assimilated empathy is used and the degree of separation is less wide, showing some amount of concern. For less responsive defaulters, cynical empathy is used and the degree of separation is much wider to enact enforcement. Thus, empathetic identification with the "other" does not necessarily arise solely from inter-subjective compassion, nor concern for social cohesion, but sometimes also from agents' perceptions of the "other."

Tax enforcement may be hostile and even physically violent (Bräutigam 2008; Cullis and Lewis 1997). This study reveals that, even in the face of large-scale evasion, it need not be so when empathy is used. However, we argue that, hidden behind tax administrators' "empathy games," TAJ obliquely wields its power to assert its legitimacy and authority, revealing "subtle coercion," as well as creating fear among some defaulters. Empathy in enforcement sometimes becomes a merely intellectual exercise, remaining squarely situated in the ethical position where "getting, acquiring, a tool to obtain an objective even though a good one" is met (Shapiro 2014, p. 279). This is so because empathetic identification with others is used as a skill rather than a moral virtue. Hence, agents are able to secure compliance, not as "conscious conformists to the regulations but as strategists ... moving through a maze of constraints and opportunities" (Swartz 1997, p. 99). Through their actions, tax administrators may unwittingly perpetuate free-riding and tax evasion among some classes of defaulters who remain "legally derelict" (Byrne 1995, p. 119), which might be considered unjust.

Governments often motivate tax administrators through the use of incentives to secure compliance and increase revenue collection. Where incentives are narrowly focused on achieving revenue collection rather than increasing tax compliance and tax morale, they may lead to increased corruption and harassment of honest citizens (see Gangl et al. 2019, p. 109), undermining justice in the tax field. As agents of the state, administrators are expected to act in the public interest, through objective enforcement of the legislation to maintain equity, fairness, and trust in the tax authority and in themselves as public servants (Murphy 2005, 2008). However, 
this may be difficult for administrators when incentives are given without accompanying sets of institutional and enabling organizational structures, which we believe are absent in this case (Mookherjee 1998 citing Klitgaard 1995). We therefore argue that, alongside the use of targets, policies should be established to ensure that institutional and organizational issues such as task assignment, appropriate legislation, adequate resource allocation, feedback, and evaluation mechanisms are independently decided and in place (Mookherjee 1998 citing Klitgaard 1995), supported by an enabling court system (Cornia and Walters 2010) to assist tax administrators in their quest to maintain tax justice.

We have found that the practice of incentivized enforcement without due consideration for organizational and institutional issues creates a number of dilemmas in the property tax field. Since tax administrators must meet their targets, to "fit IMF programme conditions," ${ }^{5}$ little attention is paid to the makeup of collections (Auditor General's Report 2016). Consequently, street-level tax administrators concentrate on defaulters who are least able to resist, leaving more resistant defaulters outside the tax net, thereby creating differential treatment of taxpayers. These hard-to-tax individuals remain without relationships with the state, as "non recognized beings," having an "irrelevant presence" (see Bahl and Wallace 2007; Bauman 1993). Differential treatment of defaulters raises issues of tax injustice and unequal treatment of taxpayers, calling into question procedural fairness (due process), and retributive (punishing non-compliance) and distributive (equalizing the tax burden) justice (Elkins 2009; OECD 2010).

Enforcing a tax system is neither an easy nor a static task in any country (Bird and Zolt 2014), but is particularly challenging for developing countries. We have noted the level of tax administrators' flexibility (May and Winter 2000) in bringing about compliance, in their bid to fulfill their ethical mandate to bring justice to the tax field and shape defaulters' morality (Björklund Larsen 2017). However, this flexibility sometimes creates dilemmas. For example, outstations expose staff to potential violence, and add another layer of administrative costs to their operations. This reflects the constant balance faced by tax administrators to get the job done, even at risk to their lives. The level of flexibility that we have identified in Jamaican enforcement practices also calls attention to the present property tax legislation (PTL) and whether it is appropriate to Jamaica's current socioeconomic

\footnotetext{
5 An interviewee from the Auditor General's Department reported this as an adverse effect of targets, as some taxpayers remain perpetually delinquent: "What you find is that they would have met their targets, because their targets are these numerical amounts to fit the IMF programme conditions, and so they focus on numbers. But you find that a lot of the entities and persons who have been regularly noncompliant continue to be" (GB03).
}

situation (Wynter and Oats 2018). This has implications for property tax policy. There are sound arguments for the PTL to be amended to reflect the socioeconomic, historical, and demographic circumstances of modern Jamaica, as articulated by Wynter and Oats (2018). Tax administrators' ability to improvise also calls into question their enforcement ethics, because in their zeal they may use questionable tactics such as veiled threats, undue pressure, and bluffing, as seen when cynical empathy, a sort of detached concern, is deployed.

Tax administrators' flexibility is also demonstrated in their tendency to concentrate on easier cases, as enforcement objectives seek not to improve tax morale but to increase revenue collections (Mansfield 1988). Although the targets may assist in providing adequate and steady revenue flows, as Bird (1992, p. 197) suggests, they may also be an "innocuous device to keep tax administrators up to the mark." Checks and balances should therefore be put in place to regulate tax administrators' enthusiasm and ensure that they keep within the bounds of the law.

Since the property tax is centrally managed in Jamaica, there is a strong argument for it to be better integrated into the general tax system. For example, linking the property tax roll with the tax registration number (TRN) database would obviate the need for the many intense searches that place a strain on already meager resources. The property tax might conceivably then be integrated with other TAJ enforcement and compliance strategies, including audit and education programs. Alternatively, the tax could be fully localized, taking its own form, which might increase tax morale rather than revenues (Guth et al. 2005).

This study also raises the much wider question of the legitimacy of the state. When a government is considered legitimate, citizens will accept whatever is asked or imposed with little protest. In Jamaica, property tax evasion rates remain high, raising the question of whether citizens are challenging the legitimacy of the state or the property tax itself. Are they saying that this tax is no longer relevant, or questioning its present form? These questions must be addressed by policymakers.

The tax roll has been a source of discontent for many years (see Cornia and Walters 2010; Auditor General's Report 2016). Around 50 percent of land parcels in Jamaica are unregistered, making it difficult to establish the true owners and occupiers of the land. This situation requires attention, as effective enforcement is largely dependent on the accuracy and completeness of the valuation roll. Identifying who is liable is of utmost importance.

One area for future research might be to examine the extent to which understandings of reasons for evasion gained through the reminder system are incorporated into tax policy reform, education, and the tax-drafting process. It is also worth considering whether using empathy brings a sustained 
change in compliant behavior, and the extent to which taxpayers' perspectives of TAJ may change based on the use of empathy in the reminder system.

\begin{abstract}
Acknowledgements We are extremely grateful for the constructive feedback of our anonymous reviewers, their comments and challenging questions went a far way in improving the paper. We also expresss sincere appreciation to our colleagues who commented on earlier drafts of the paper at conferences and seminars. Lynne Oats gratefully acknowledges the financial support of the Economic and Social Research Council under grant reference ES/S00713X/1.
\end{abstract}

\section{Compliance with Ethical Standards}

Conflict of interest The authors declare that they have no conflict of interest.

Ethical Approval All procedures performed in the studies involving human participants were in accordance with the ethical standards of the institutional and/or national research committee and with the 1964 Helsinki Declaration and its later amendments or comparable ethical standards.

Informed Consent Informed consent was obtained from all individual participants included in this study.

Open Access This article is distributed under the terms of the Creative Commons Attribution 4.0 International License (http://creativeco mmons.org/licenses/by/4.0/), which permits unrestricted use, distribution, and reproduction in any medium, provided you give appropriate credit to the original author(s) and the source, provide a link to the Creative Commons license, and indicate if changes were made.

\section{Appendix: Jamaican Property Tax Procedures}

\section{Number of Properties and Maintenance of Valuation Roll}

Every property (including those exempt from property tax) is listed on the valuation roll, totaling over 800,000. Properties are listed by district, bearing the name, nationality, and postal address of the property's owner, its situation, description, and measurements (see Land Valuation Act 1957). Maintenance of the roll is the responsibility of the Commissioner of Lands (see Land Valuation Act, SS17, 24 $\& 25$ ), who provides a copy of the valuation roll to TAJ on its completion or whenever there is an amendment to the roll. Importantly, the roll is not always accurate, which complicates the property tax collection process.

\section{Tax Liabilities and Payment Cycles}

Property tax, based on the unimproved value of the land, is payable annually by owners, occupiers, mortgagors, or anyone in actual possession of the property when the tax becomes due and payable. In 2012 the rate was $\mathbf{J} \$ 1000$ (US\$10) for properties up to $\mathrm{J} \$ 300,000$, and thereafter 0.75 percent of a dollar for each dollar of value above $\mathrm{J} \$ 300,000$. In 2013 there was a rate change, whereby all properties with an unimproved value up to $\mathrm{J} \$ 100,000$ were charged a flat rate of J $\$ 1000$. Properties with values exceeding J\$100,000 up to $\mathrm{J} \$ 1$ million attracted an additional 1.5 percent for every additional dollar above $\mathrm{J} \$ 100,000$. Properties with values exceeding J $\$ 1$ million were subject to an additional 2.0 percent for every additional dollar.

Taxpayers may pay their tax in either annual, biannual, or quarterly installments at any of the 29 collecting stations or through TAJ's online portal. Property tax arrears are huge. In this regard, Tharkur $(2010$, p. 2$)$ states that property tax revenues fell precipitously across almost all valuation categories, leading to arrears at over J $\$ 5$ billion ( $0.5 \%$ of GDP) by the end of 2009, making weak enforcement a major factor in revenue decline (see also Beale and Wyatt 2017; Cornia and Walters 2010; Wynter and Oats 2018).

\section{Governing Legislation and Enforcement Conditions}

The PTL-comprising the Property Tax Act of 1903 (PTA), the Land Valuation Act (1957), and the Government of Jamaica (1867)-Tax Collection Act (TCA) - provides for notifications of liability through assessment notices, either personally served, left at the taxpayer's address, or sent by registered post to the taxpayer's address (see PTA S3(2) \& (3)). There is a statutory bar on enforcing liabilities due for over 6 years, which puts pressure on the tax administration. For those who default, the PTL stipulates that one notice must be sent to them, informing them of their outstanding liability and requiring them to settle in full within 15 days of receipt of this notice. Where defaulters refuse to settle as required, legal remedies include being sued for the arrears plus full litigation costs, creation of a lien against their property, or, in extreme cases, seizure and forfeiture of their property.

The PTL provides an exemption for those who are poverty-stricken, making it mandatory for TAJ to report any defaulter deemed to be poverty-stricken to the Minister of Finance, and for tax administrators to assist such defaulters in completing the necessary documentation to enable exemption.

\section{Notices and the Mail System}

The Ministry of Local Government is responsible for both printing and circulating assessment notices to taxpayers. High-value notices are hand-delivered by contracted personnel appointed by the local authorities, while all other assessment notices are sent by regular mail to taxpayers. 
There is no mechanism for TAJ to ascertain to whom notices have been sent. Some taxpayers complain that they have not received assessment notices. Owing to logistics in Jamaica, many addresses have no door number, road or street name, just a district and parish. Taxpayers collect their mail from postal agencies in their districts or, where there are no postal agencies, from the post office in the nearest town to their district. The mail system is known to be unreliable.

\section{Reminder System and Targets}

The reminder system for property tax arrears commenced in 2006, at which time local authorities were required to partner with TAJ for arrears collection (see Ministry of Local Government 1993, 2003). At that time the arrears amounted to J\$546 million, rising to J\$6.4 billion in $2012 / 13$ and to J\$13.4 billion in 2016/17. From time to time, the government has had to write off large portions of property tax arrears through the Tax Collection Act (see, for example, Order No 9, 2013). To minimize the arrears write-offs, a report commissioned by the Office of the Prime Minister in 2010 recommended that TAJ should "articulate the expectations for all members of the property tax team specifying performance targets for each reporting period" (Cornia and Walters 2010, p. 20). Although the report did not give a specific start date, targets appear to have been established around 2011/2012, as the Auditor General's Department, in its report covering the 2011/2012 to 2015/2016 periods, stated a collection target of 20 percent for property tax arrears. Such targets are established through collaboration between TAJ, the Ministry of Local Government and Community Development (MLG\&CD), and the Ministry of Finance and Public Services, subject to Cabinet approval. However, the MLG\&CD seems to set the targets and communicate them to TAJ (Government of Jamaica 2016a, b-Property tax collections and enforcement, Auditor General's Report), based on incrementalism rather than any objective scientific principles, according to a senior government bureaucrat. Not all arrears are collectable.

\section{References}

Alasfour, F. (2017). Cost of distrust: The virtuous cycle of tax compliance in Jordan. Journal of Business Ethics, 155(1), 243-258.

Alm, J., \& Martinez-Vazquez, J. (2007). Tax morale and evasion in Latin America. Working paper, Atlanta, GA: Andrew Young School of Policy, Georgia State University.

Alm, J., \& Torgler, B. (2011). Do ethics matter? Tax compliance and morality. Journal of Business Ethics, 101(4), 635-651.

Bahl, R. (2009). Property tax reform in developing and transition countries. Washington, DC: USAID

Bahl, R. W., \& Bird, R. M. (2008). Tax policy in developing countries: Looking back—and forward. National Tax Journal, 61(2), 279-301.
Bahl, R., \& Wallace, S. (2007). Comprehensive tax reform in Jamaica. Public Finance Review, 35(1), 4-25.

Battaly, H. D. (2011). Is empathy a virtue? In A. Coplan \& P. Goldie (Eds.), Empathy: Philosophical and psychological perspectives (pp. 277-301). Oxford: Oxford University Press.

Bauman, Z. (1993). Postmodern ethics. Oxford: Basil Blackwell.

Beale, T., \& Wyatt, P. (2017). Predicting taxpayer behaviour and compliance: An economic analysis of Jamaica's property tax system. Paper presented at the Annual World Bank Conference on Land and Poverty, Washington, DC, 20-24 March.

Bernstein, T. P., \& Lü, X. (2008). Taxation and coercion in rural China. In D. Bräutigam, O.-H. Fjeldstad, \& M. Moore (Eds.), Taxation and state-building in developing countries (pp. 89-109). Cambridge: Cambridge University Press.

Bird, R. M. (1992). Tax policy and economic development. Baltimore, MD: John Hopkins University Press.

Bird, R. M. (2015). Improving tax administration in developing countries. Journal of Tax Administration, 1(1), 23-45.

Bird, R. M., \& Zolt, E. M. (2014). Redistribution via taxation: The limited role of the personal income tax in developing countries. Annals of Economics and Finance, 15(2), 625-683.

Björklund Larsen, L. B. (2013). Moulding knowledge into a legal complex: Para-ethnography at the Swedish Tax Agency. Journal of Business Anthropology, 2(2), 209-231.

Björklund Larsen, L. B. (2015). Common sense at the Swedish Tax Agency: Transactional boundaries that separate taxable and tax-free income. Critical Perspectives on Accounting, 31, $75-89$.

Björklund Larsen, L. B. (2017). Shaping taxpayers: Values in action at the Swedish Tax Agency. Oxford: Berghahn Books.

Bobek, D. D., Hageman, A. M., \& Radtke, R. R. (2010). The ethical environment of tax professionals: Partner and non-partner perception experiences. Journal of Business Ethics, 92(4), 637-654.

Boden, R., Killian, S., Mulligan, E., \& Oats, L. (2010). Critical perspectives on taxation. Critical Perspectives on Accounting, 21(7), 541-544.

Boll, K. (2011). The responsive raid: An analysis of the dual logics of generalization in judging businesses' tax compliance and in doing responsive regulation. STS Encounters, 4(2), 7-41.

Boll, K. (2014). Shady car dealings and taxing work practices: An ethnography of a tax audit process. Accounting, Organizations and Society, 39(1), 1-19.

Bourdieu, P. (1977). Outline of a theory of practice. Cambridge: Cambridge University Press.

Bourdieu, P. (1990). The logic of practice. Redwood City, CA: Stanford University Press.

Bourdieu, P. (1998). Practical reason: On the theory of action. Redwood City, CA: Stanford University Press.

Bourdieu, P., \& Wacquant, L. J. (1992). An invitation to reflexive sociology. Chicago, IL: University of Chicago Press.

Braithwaite, V. (2003). Dancing with tax authorities: Motivational postures and no-compliant actions. In V. Braithwaite (Ed.), Understanding tax avoidance and evasion (pp. 15-39). Aldershot: Ashgate Publishing Ltd.

Braithwaite, V. (2006). Is reintegrative shaming relevant to tax evasion and avoidance? In H. Elffers, P. Verboon, \& W. Huisman (Eds.), Managing and maintaining compliance: Closing the gap between science and practice (pp. 109-127). The Hague, Netherlands: Boom Legal Publishers.

Braithwaite, V. (2009). Defiance in taxation and governance: Resisting and dismissing authority in a democracy. Cheltenham: Edward Publishing.

Braun, V., \& Clarke, V. (2006). Using thematic analysis in psychology. Qualitative Research in Psychology, 3(2), 77-101. 
Bräutigam, D. (2008). Introduction: Taxation and state-building in developing countries. In D. Bräutigam, O. H. Fjeldstad, \& M. Moore (Eds.), Taxation and state building in developing countries: Capacity and consent (pp. 1-33). Cambridge: Cambridge University Press.

Bringer, J. D., Johnston, L. H., \& Brackenridge, C. H. (2006). Using computer-assisted qualitative data analysis software to develop a grounded theory project. Field Methods, 18(3), 245-266.

Browde, P. (2017). A reflection on tax collections: Opening a can of worms to clean up a collection due process jurisdictional mess. Drake Law Review, 65(1), 51-87.

Bubandt, N., \& Willerslev, R. (2015). The dark side of empathy: Mimesis, deception, and the magic of alterity. Comparative Studies in Society and History, 57(1), 5-34.

Byrne, E. (1995). Public goods and the paying public. Journal of Business Ethics, 14(2), 117-123.

Chung, J., \& Trivedi, V. U. (2003). The effect of friendly persuasion and gender on tax compliance behavior. Journal of Business Ethics, 47(2), 133-145.

Clark, R. D., \& Word, L. E. (1974). Where is the apathetic bystander? Situational characteristics of the emergency. Journal of Personality and Social Psychology, 29(3), 279-287.

Clarke, E. (1999). My mother who fathered me: A study of the families in three selected communities of Jamaica. Mona, Jamaica: University of West Indies Press.

Coke, J. S., Batson, C. D., \& McDavis, K. (1978). Empathic mediation of helping: A two-stage model. Journal of Personality and Social Psychology, 36(7), 752-766.

Coplan, A. (2011). Will the real empathy please stand up? A case for a narrow conceptualization. The Southern Journal of Philosophy, 49(S1), 40-65.

Cornia, G., \& Walters, L. C. (2010). Improving the property tax in Jamaica: Issues and options. Kingston, Jamaica: Government of Jamaica.

Creswell, J. W. (2013). Research design: Qualitative, quantitative, and mixed methods approaches. Thousand Oaks, CA: Sage Publications.

Cullis, J. G., \& Lewis, A. (1997). Why people pay taxes: From a conventional economic model to a model of social convention. Journal of Economic Psychology, 18(2-3), 305-321.

De Cesare, C. (2004). Thoughts on the fiscal reform in Brazil: Looking at the property tax. Journal of Property Tax Assessment \& Administration, 1(2), 57-69.

Dillinger, W. (1992). Urban property tax reform: Guidelines and recommendations. Washington, DC: International Bank of Reconstruction.

Elkins, D. (2009). Taxation and the terms of justice. University of Toledo Law Review, 41, 73-105.

Galinsky, A. D., Maddux, W. W., Gilin, D., \& White, J. (2008). Why it pays to get inside the head of your opponent: The differential effects of perspective taking and empathy in negotiations. Psychological Science, 19(4), 378-384.

Gangl, K., Hart, B., Hoffman, E., \& Kirchler, E. (2019). The relationship between Austrian tax auditors and self-employed taxpayers: Evidence from a qualitative study. Frontiers in Psychology, 10, 1034. https://doi.org/10.3389/fpsyg.2019.01034.

Gill, J. B. (2000). A diagnostic framework for revenue administration. Washington, DC: World Bank Publications.

Government of Jamaica. (1867). The tax collection act. Kingston, Jamaica: Government of Jamaica.

Government of Jamaica. (1996). National land policy. Kingston, Jamaica: Government of Jamaica.

Government of Jamaica. (2012). Report of Offices of the Services Commissions. Kingston, Jamaica: Government of Jamaica.

Government of Jamaica. (2016a). Auditor general's audit performance reports. Kingston, Jamaica: Government of Jamaica.
Government of Jamaica. (2016b). Property tax collections and enforcement at TAJ. Auditor General's Report.

Gracia, L., \& Oats, L. (2012). Boundary work and tax regulation: A Bourdieusian view. Accounting, Organizations and Society, $37(5), 304-321$.

Graham, N. (2016). From the womb to the tomb via Jamaica's $\$ 800$ million informal economy. The Gleaner, 1 November. Retrieved July 30, 2019, from http://jamaica-gleaner.com/artic le/news/20161101/womb-tomb-jamaicas-800-million-infor mal-enonomy.

Gruen, L. (2014). Entangled empathy: An alternative for our relationships with animals. Brooklyn, NJ: Lantern Books.

Guth, W., Levati, V., \& Sausgruber, R. (2005). Tax morale and (de) centralization: An experimental study. Public Choice, 125(12), 171-188

Halpern, J. (2001). From detached concern to empathy: Humanizing medical practice. Oxford: Oxford University Press.

Halpern, J. (2014). Clinical empathy in medical care. In J. Decety (Ed.), Empathy: From the bench to bedside (pp. 229-244). Cambridge: The MIT Press.

Harriott, A. (2003). Understanding crime in Jamaica: New challenges for public policy. Mona, Jamaica: University of the West Indies Press.

Harris, J. (2007). The evolutionary neurobiology, emergence and facilitation of empathy. In T. Farrow \& P. Woodruff (Eds.), Empathy in mental illness (pp. 168-186). Cambridge: Cambridge University Press.

Hasseldine, J., \& Li, Z. (1999). More tax evasion research required in the new millennium. Crime, Law and Society, 31(1), 91-104.

Head, N. (2016). A politics of empathy: Encounters with empathy in Israel and Palestine. Review of International Studies, 42(1), 95-113.

Hoffman, M. L. (2001). Empathy and moral development: Implications for caring and justice. Cambridge: Cambridge University Press.

Hollan, D. (2008). Being there: On the imaginative aspects of understanding others and being understood. Ethos, 36(4), 475-489.

Hollan, D. (2012). Emerging issues in the cross-cultural study of empathy. Emotional Review, 4(1), 70-78.

Hollan, D. W., \& Troop, C. J. (Eds.). (2011). The anthropology of empathy: Experiencing the lives of others in Pacific societies. New York, NY: Berghahn Press.

Hutter, B. (1989). Variations in regulatory enforcement styles. Law and Policy, 11(2), 153-174.

Keen, S. (2008). Strategic empathizing: Techniques of bounded, ambassadorial, and broadcast narrative empathy. Deutsche Vierteljahrsschrift für Literaturwissenschaft und Geistesgeschichte, 82(3), 477-493.

Komorosky, D., \& O'Neal, K. K. (2015). The development of empathy and prosocial behavior through humane education, restorative justice, and animal-assisted programs. Contemporary Justice Review, 18(4), 395-406.

Kornhauser, M. E. (2006). A tax morale approach to compliance: Recommendations for the IRS. Florida Tax Review, 8(6), 599-632.

Levi, M. (1988). Of rule and revenue. Berkeley, CA: University of California Press.

Lobb, A. (2017). Critical empathy. Wiley. Constellations, 24(4), 594-607.

Local Authorities of Jamaica (2016). Property tax. Kingston, Jamaica: Local Authorities of Jamaica. Retrieved June 21, 2016, from http://www.localauthorities.gov.jm/property-tax/background.

Lohmann, R. (2011). Empathetic perception and imagination among the Asabano: Lessons for anthropology. In D. W. Holland \& C. J. Troop (Eds.), The anthropology of empathy: Experiencing the lives of others in Pacific Societies (pp. 95-116). New York, NY: Berghahn Books. 
Mansfield, C. Y. (1988). Tax administration in developing countries: An economic perspective. IMF Staff Papers, 35(1), 181-197.

Marsh, A. (2014). Empathy and compassion: A cognitive neuroscience perspective. In J. Decety (Ed.), Empathy: From bench to bedsite (pp. 199-205). Cambridge, MA: MIT Press.

Marshall, M. N. (1996). Sampling for qualitative research. Family Practice, 13(6), 522-526.

Martin, I. W., Mehrotra, A. K., \& Prasad, M. (2009). The thunder of history: The origins and development of the new fiscal sociology. Cambridge: Cambridge University Press.

Martinez-Vazquez, J., \& Sepulveda, C. (2011). Explaining property tax collections in developing countries: The case of Latin America. Working Paper 11-09, Atlanta, GA: Andrew Young School for Policy Studies, Georgia State University.

May, P. J., \& Winter, S. (2000). Reconsidering regulatory enforcement: Patterns in Danish agro-environmental inspection. Law and Policy, 22(2), 143-173.

May, P. J., \& Wood, R. S. (2003). At the regulatory front lines: Inspectors' enforcement styles and regulatory compliance. Journal of Public Administration Theory and Research, 13(2), $117-139$.

McAllister, L. (2010). Dimensions of enforcement styles: Factoring in regulatory autonomy and capacity. Law and Policy, 32(1), 61-78.

McCluskey, W. J., \& Franzsen, R. (2005). An evaluation of the property tax in Tanzania: An untapped fiscal resource or administrative headache? Property Management, 23(1), 43-69.

McKerchar, M., \& Evans, C. (2009). Sustaining growth in developing economies through improved taxpayer compliance: Challenges for policymakers and revenue authorities. eJournal of Tax Research, 7, 171-201.

Merriam, S. (2002). Qualitative research in practice: Examples for discussion and analysis. San Francisco, CA: Jossey-Bass.

Miles, M. B., \& Huberman, A. M. (1994). Qualitative data analysis: An expanded sourcebook. Thousand Oaks, CA: Sage.

Ministry of Local Government. (1993). Ministry Paper 8/93: Reform of Local Government. Kingston, Jamaica: Ministry of Local Government.

Ministry of Local Government. (2003). Ministry Paper 7/03: Local Government Reform. Kingston, Jamaica: Ministry of Local Government.

Mookherjee, D. (1998). Incentives reforms in Developing Country bureaucracies: Lessons from tax administrations. In B, Pleskovic \& J. Stiglitz (Eds.), Annual World Bank Conference 1997 in Development Economics (pp. 103-124). The World Bank.

Murphy, K. (2005). Regulating more effectively: The relationship between procedural justice, legitimacy, and tax non-compliance. Journal of Law and Society, 32(4), 562-589.

Murphy, K. (2008). Enforcing tax compliance: To punish or persuade. Economic Analysis and Policy, 38(1), 113-135.

Nerré, B. (2008). Tax culture: A basic concept for tax politics. Economic Analysis and Policy, 38(1), 153-167.

Nordin, Z. S., Muhammead, I., Wahab, A. K., \& Yaakub, N. A. (2017). Co-operation, tax complexity and managerial control: A study on tax auditors' conciliatory style. Asian Journal of Business and Accounting, 10(2), 165-186.

OECD. (2010). Understanding and influencing taxpayers' compliance behaviour. Paris, France: OECD.

Patton, M. Q. (1990). Qualitative evaluation and research methods. Thousand Oaks, CA: Sage Publications.

Pentland, B. T., \& Carlile, P. (1996). Audit the taxpayer, not the return: Tax auditing as an expression game. Accounting, Organizations and Society, 21(2), 269-287.

Powers, S. (2008). Collection and enforcement of the property tax. In R. Bahl, J. Martinez-Vazquez, \& J. Youngman (Eds.), Making the property tax work (pp. 372-386). Cambridge, MA: Lincoln Land Policy Institute.
Prinz, J. (2011). Is empathy necessary for morality? In A. Coplan \& P. Goldie (Eds.), Empathy: Philosophical and psychological perspectives (pp. 211-229). Oxford: Polity Press.

Rufkin, J. (2009). The empathic civilization: The race to global consciousness in a world in crisis. London: Penguin.

Shapiro, J. (2014). The paradox of teaching empathy in medical education. In D. Decety (Ed.), Empathy from bench to bedside (pp. 274-290). Cambridge, MA: MIT Press.

Silvani, C., \& Baer, K. (1997). Designing a tax administration reform strategy: Experiences and guidelines. IMF Working Paper WP/97/30, Washington, DC: International Monetary Fund.

Silverman, D. (2013). Doing qualitative research: A practical handbook. Thousand Oaks, CA: Sage Publications.

Swartz, D. (1997). Culture and power: The sociology of Pierre Bourdieu. Chicago, IL: University of Chicago Press.

TAJ (2012). Citizen's charter. Kingston, Jamaica: Tax Administration Jamaica. Retrieved July 30, 2019, from https://www.jamaicatax .gov.jm/documents/10181/106840/taj_citizens_charter.pdf/1a796 756-ed5b-4322-a5b8-d5c6bf78e2f7.

TAJ (2016). Citizen's charter. Kingston, Jamaica: Tax Administration Jamaica. Retrieved September 12, 2016, from https://www.jamai catax.gov.jm/citizen-s-charter.

Tanzi, V., \& Zee, H. H. (2001). Tax policy for developing countries (Vol. 27). Washington, DC: International Monetary Fund.

Tennant, S., \& Tennant, D. (2007). The efficiency of tax administration in Jamaica: An introspective assessment. Social and Economic Studies, 56(3), 71-100.

Tharkur, M. A. (2010). Policy briefs: Property tax reform and performance in Jamaica. MA, USA: Harvard Kennedy School of Government.

Tracy, S. J. (2010). Qualitative quality: Eight "big-tent" criteria for excellent qualitative research. Qualitative Inquiry, 16(10), $837-851$.

Tuck, P. (2010). The emergence of the tax official into a T-shaped knowledge expert. Critical Perspectives on Accounting, 21(7), 584-596.

Vann, L. (2017). Demonstrating empathy: A phenomenological study of instructional designers making instructional strategy decisions for adult learners. International Journal of Teaching and Learning in Higher Education, 29(2), 233-244.

Vehorn, C. L. (2011). Fiscal adjustment in developing countries through tax administration reform. The Journal of Developing Areas, 45(1), 323-338.

Waldman, M. (2014). Strategic empathy: The Afghanistan intervention shows why the U.S. must empathize with its adversary. MA, USA: Belfer Center for Science and International Affairs, John F. Kennedy School of Government, Harvard University.

Wispé, L. (1986). The distinction between sympathy and empathy: To call forth a concept, a word is needed. Journal of Personality and Social Psychology, 50(2), 314-321.

Wedderburn, C., Chiang, P., \& Rhodd, R. (2012). The informal economy in Jamaica: Is it feasible to tax this sector? Journal of International Business and Cultural Studies, 6, 1.

Wynter, C. (2014). Property tax administration in practice: A case study of the Portmore Municipality, Jamaica. $\mathrm{PhD}$ thesis, University of Exeter, Exeter.

Wynter, C., \& Oats, L. (2018). Don't worry, we are not after you! Anancy culture and tax enforcement in Jamaica. Critical Perspectives on Accounting, 57, 56-69.

Publisher's Note Springer Nature remains neutral with regard to jurisdictional claims in published maps and institutional affiliations. 